\title{
ANALISIS KESALAHAN SISWA DALAM MENGERJAKAN SOAL CERITA TRIGONOMETRI
}

\author{
Ika Diah Pratiwi ${ }^{1}$, Aritsya $^{2}$, Yanti $^{3}$ \\ Program Studi Pendidikan Matematika, Universitas Muhammadiyah Sukabumi ${ }^{1,2,3}$ \\ e-mail: ikadiah200@gmail.com
}

\begin{abstract}
ABSTRAK
Penelitian ini bertujuan untuk mengidentifikasi apa saja kesalahan siswa dalam menyelesaikan soal cerita trigonometri di SMA PLUS YASPIDA Kota Sukabumi tahun ajaran 2020/2021. Jenis penelitian ini menggunakan metode deskriptif kualitatif. Subjek pada penelitian ini adalah siswa kelas XI SMA PLUS YASPIDA Kota Sukabumi dengan pengambilan subjeknya adalah purposive sampling. Teknik pengumpulan data berupa tes, wawancara, dan dokumentasi. Teknik analisis data yang digunakan, yaitu reduksi data, penyajian data, dan penarikan kesimpulan. Berdasarkan hasil penelitian menunjukkan bahwa adanya kesalahan yang dilakukan siswa dalam menyelesaikan soal cerita trigonometri sebagai berikut : (1) kesalahan konsep yaitu kesalahan diswa tidak dapat menuliskan/mengidentifikasi apa yang diketahui dan dicari, ketidakmampuan siswa dalam mentransformasikan kalimat ke dalam model matematika, dan kurangnya penguasaan konsep yang diterapkan. (2) kesalahan prinsip yaitu siswa membaca soal kurang tepat sehingga terjadi kesalahan penafsiran, sulit memahami bahasa yang kurang familiar, mengakibatkan adanya kesalahan dalam menentukan rumus yang digunakan. (3) kesalahan operasi kesalahan perhitungan dalam betuk akar dan mengoperasikan bilangan penyebab munculnya kesalahan ini dikarenakan siswa kurang teliti melakukan perhitungan.

Kata kunci :

Kesalahan siswa, Soal cerita, Trigonometri
\end{abstract}

ABSTRACT

This study aims to identify the mistakes of students in solving trigonometric story questions at SMA PLUS YASPIDA Sukabumi in the academic year 2020/2021. This type of research uses a qualitative descriptive method. Subjects in this study were students of class XI SMA PLUS YASPIDA Sukabumi City with the subject of purposive sampling. Data collection techniques in the form of tests, interviews, and documentation. The data analysis techniques used were data reduction, data presentation, and conclusion drawing. Based on the results of the study, it shows that there are mistakes made by students in solving trigonometric story problems as follows: (1) misconceptions, namely errors in students being unable to write / identify what is known and sought, the inability of students to transform sentences into mathematical models, and lack of mastery applied concept. (2) the principle error is that students read the questions inappropriately, resulting in misinterpretation, difficulty understanding unfamiliar language, resulting in errors in determining the formula used. (3) the error in the operation of the calculation error in the root form and operating the number that causes this error is due to the students being less careful in doing calculations.

Keywords :

Student error; Question of story, Trigonometri

PENDAHULUAN

Matematika adalah ilmu yang memiliki kajian berupa fakta, konsep, prosedur, dan prinsip yang bersifat abstrak. Konsep yang telah dipelajari siswa merupakan konsep dasar untuk menguasai konsep pada materi selanjutnya, oleh sebab itu konsep matematika saling berhubungan satu sama lain. Dalam mempelajari matematika, siswa dituntut untuk dapat menghubungkan konsep matematika yang nantinya akan berguna dalam proses pemecahan masalah. Priyanto (2015) berpendapat bahwa pemecahan masalah dalam matematika, biasanya diwujudkan dalam soal cerita yang merupakan soal dibuat dalam bentuk cerita serta berkaitan dengan kehidupan sehari-hari. Susanti 


\section{$\pi$ (Phi)}

(2017) menambahkan, soal cerita cenderung lebih sulit untuk dipecahkan disbanding soal yang hanya mengandung bilangan. Memecahkan soal cerita, siswa dituntut untuk mampu memahami isi soal cerita tersebut, mengetahui obyek-obyek matematika yang harus diselesaikan. Siswa pun harus mampu memisalkannya ke dalam model matematika, kemudian mampu memilih operasi hitung yang tepat, hingga akhirnya penyelesaian serta penarikan kesimpulan.

Dalam pembelajaran matematika siswa cenderung memahami konsep materi yang sedang dipelajari namun dalam menerapkan rumus yang akan digunakan salah. Sedangkan, siswa yang tidak mengerti mengenai konsep materi yang sedang dipelajari dapat menyelesaikan masalah matematika menghasilkan jawaban dengan unsur logika dari diri sendiri. Begitu pula dengan kesalahan siswa yang sering terjadi karena kesalahan perhitungan. Siswa memahami konsep dan prosedur pada materi yang sedang dipelajari, akan tetapi siswa seringkali tidak teliti dengan perhitungan atau komputasi sehingga menyebabkan adanya kesalahan pada permasalahan matematika (Sahriah, 2012). Siswa perlu adanya analisis untuk mengetahui kesalahan apa saja dan mengapa kesalahan tersebut dilakukan siswa. Maka dari itu akan diperoleh bentuk dan penyebab kesalahan siswa, sehingga guru dapat memberikan jenis bantuan kepada siswa.

Sebagian siswa merasa kesulitan memecahkan masalah soal cerita yaitu dalam memahami maksud, apa yang ditanyakan dari soal cerita karena setiap soal yang berbeda mempunyai penyelesaian yang berbeda pula sehingga siswa sulit dalam membuat model matematika. Selain itu masih banyak pula kesalahan dalam perhitungan. Mulyono (2010) hal ini dikarenakan dalam menyelesaikan soal
Jurnal Pendidikan Matematika Volume 5 Nomor 1 Tahun 2021 uraian matematika berbentuk cerita diperlukan pemahaman dan pemikiran logis.

Adanya kesalahan yang dilakukan siswa dalam memecahkan masalah matematika menjadi petunjuk sejauh mana penguasaan siswa terhadap materi. Maka dari itu perlu dianalisis untuk mengetahui kesalahan apa saja yang dilakukan siswa dan apa yang menjadi penyebab dari kesalahan tersebut, sehingga ketika menyelesaikan soal matematika dapat mengurangi tingkat kesalahannya.

\section{METODE PENELITIAN}

Jenis penelitian ini berdasarkan pendekatan kualitatif, karena datanya bersifat non statistik. Penelitian ini bertujuan untuk memperoleh informasi yang lebih mendalam tentang jenis kesalahan siswa dalam menyelesaikan soal cerita trigonometri. Subjek penelitian ini adalah siswa kelas XI SMA PLUS YASPIDA Sukabumi tahun ajaran 2020/2021, subjek penelitian terdiri dari 1 siswa berkemapuan tinggi, 1 siswa berkemampuan sedang, dan 1 siswa berkemampuan rendah. Teknik pengambilan subjek adalah purposive sampling, karena tidak semua sampel memenuhi kriteria. Oleh sebab itu, sampel yang dipilih ditentukan berdasarkan tes yang diberikan kepada siswa.

Teknik pengumpulan data yang kedua adalah wawancara dimana hasil wawancara akan digunakan sebagai pedoman bagi peneliti untuk mengetahui apa saja kesalahan yang dilakukan siswa dalam menyelesaikan soal cerita trigonometri. Pengumpulan data yang ketiga adalah dokumentasi untuk menganalisis dokumendokumen yang berkaitan dengan penelitian,seperti hasil kerja siswa dalam menyelesaikan tes kesalahan siswa dalam bentuksoal cerita. Teknik analisis data yang digunakan, yaitu reduksi data, penyajian data, dan penarikan kesimpulan. 


\section{HASIL DAN PEMBAHASAN}

Dari hasil analisis jawaban pada lembar tes siswa, ditemukan jenis kesalahan yang dilakukan oleh siswa berdasarkan indikator. Indikator yang digunakan dalam penelitian ini adalah indikator yang dikemukakan oleh Alfin (2017), dapat dilihat pada Tabel 1.

Tabel 1. Indikator Analisis Kesalahan Siswa dalam Menyelesaikan Soal Matematika

\begin{tabular}{ll}
\hline \multicolumn{1}{c}{ Kesalahan } & \multicolumn{1}{c}{ Indikator Kesalahan } \\
\hline Kesalahan Konsep & Salah dalam memahami makna soal dan salah dalam menggunakan konsep \\
& variabel yang digunakan. \\
& Salah dalam tidak menuliskan rumus, teorema atau definisi untuk menjawab \\
& permasalahan. \\
& Tidak menjawab soal sehingga tidak ada penyelesaian. \\
& Salah dalam menerjemahkan soal. \\
& Salah dalam tidak memperhatikan prasyarat dalam menggunakan rumus, \\
& teorema atau definisi. \\
Kesalahan Prinsip & Tidak dapat menyelesaikan soal sampai tuntas atau selesai. \\
& Salah dalam melakukan langkah-langkah yang tidak hirarkis. \\
& Tidak menyelesaikan soal sampai tuntas atau selesai. \\
& Salah dalam perhitungan. \\
\hline
\end{tabular}

1) Kesalahan Konsep

Khasanah (2015) menyatakan siswa harus memiliki pengetahuan sematik yaitu pengetahuan yang membantu siswa untuk memahami tujuan masalah dan menafsirkan masalah dengan benar. Oleh karena itu, untuk meminimalisir tingkat kesulitan siswa dalam memahami maksud soal, sehingga dapat menafsirkan maksud soal serta menganalisis segala permasalahan

Jika siswa tidak menuliskan dengan detail apa yang diketahui dan ditanyakan, maka dapat berakibat pada kesalahan ditahap selanjutnya, seperti kesalahan pada saat mensubtitusikan apa yang diketahui terhadap rumus yang digunakan. Bisa saja siswa lupauntuk menuliskan haltersebut karena lupa atau tidak dibiasakan untuk menulis apa yang diketahui dan ditanyakan untuk menyelesaikan permasalahan.

Kesalahan yang biasa dilakukan oleh siswa termasuk kedalam kesalahan konsep, yaitu kesalahan dengan tidak dituliskan apa saja yang diketahui dan ditanyakan. Menimbulkan adanya kesalahan dalam menyelesaikan soal.

Berikut merupakan kesalahan konsep yang dilakukan siswa dalam mengerjakan soal no 4.

Soal no 4 : Sebidang tanah berbentuk segitiga dengan setiap titik sudutnya diberi tonggak pembatas $A, B$ dan $C$. Jika jarak antara tonggak $A$ dan $B$ adalah $300 \mathrm{~m}$, sudut $A B C 45^{\circ}$ dan sudut BCA $60^{\circ}$. Hitunglah jarak antara tonggak $A$ dan $C$ ! 


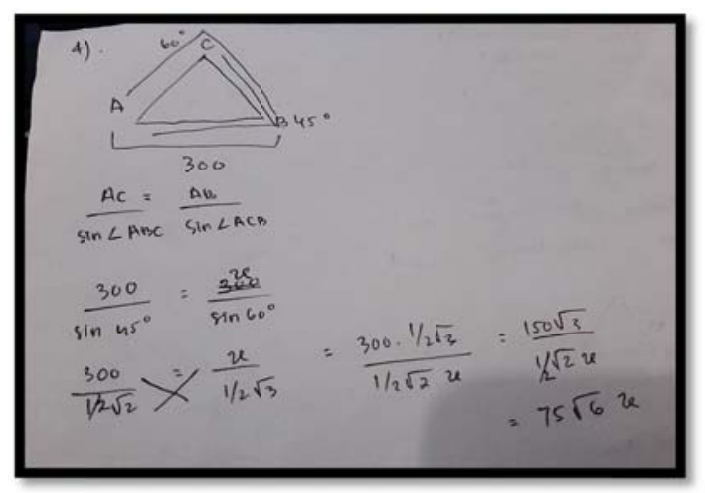

Gambar 1. Kesalahan Konsep

Berdasarkan hasil analisis tes pada siswa dapat disimpulkan bahwa kesalahan pemahaman yang dilakukan siswa, tidak menuliskan apa yang diketahui dalam soal dan tidak menuliskan apa yang ditanyakan dalam soal. Menurut penelitian yang dilakukan oleh Chusnul (2017) siswa melakukan kesalahan pemahaman dengan tidak menuliskan informasi dan pertanyaan.

Kemampuan membaca soal dengan tepat perlu dimiliki siswa agar tidak membuat penafsiran yang berbeda. Terbukti ada siswa yang diminta untuk membacakan soal saat diwawancara mampu membaca soal yang diberikan. Kemampuan membaca tepat sangat diperlukan oleh seseorang sebagai modal utama untuk menyelesaikan soal cerita. Namun, mayoritas siswa tidak memahami cerita pada soal, kunci utama dalam menyelesaikan soal adalah memahami soal supaya tidak adanya kesalahan dalam menentukan model matematika. Hal ini sejalan dengan pendapat Erliani (2011) yang berpandangan bahwa soal cerita yang disajikan dengan bahasa yang sudah dikuasai siswa dengan baik, ternyata akan mempermudah siswa dalam mengubah ke model matematika.

2) Kesalahan Prinsip

Kesalahan prinsip salah satu dari aspeknya adalah kesalahan dalam menentukan rumus yang digunakan untuk menyelesaikan permasalahan. Namun pada kenyataannya siswa masih banyak yang lupa rumus yang digunakan. Bahkan ada pula yang pemahaman rumusnya salah ataupun hanya mengingat sedikit-sedikit saja.

Berikut merupakan kesalahan konsep yang dilakukan siswa dalam mengerjakan soal no 5 .

Soal no 5 : Pak Maman seorang nelayan yang ingin berlayar kearah timur untuk menangkap ikan sejauh $120 \mathrm{~km}$, kemudian memutar kemudinya dengan membentuk $60^{\circ}$ sejauh 100 km hingga berhenti. Jarak kapal dari mula-mula titik berlayar ke tempat pemberhentian adalah...

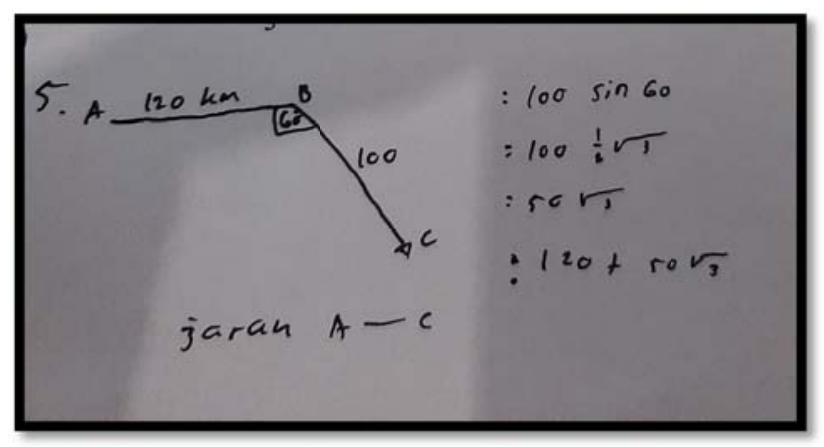

Gambar 2. Kesalahan Prinsip 
Berdasarkan jawaban tersebut, siswa tidak menuliskan rumus, teorema atau definisi untuk menjawab permasalahan. Pada hasil wawancara dengan siswa mengatakan bahwa siswa tidak tahu harus menggunakan rumus yang mana, karena kesulitan dalam memahami soal. Sejalan dengan pendapat Sepeng P dan Suthembile Sigola (2013) menggambarkan bahwa siswa mengalami kesulitan dalam membaca dan memahami masalah dengan bahasa matematis, dengan menghasilkan siswa tidak dapat menyelesaikan permasalahan.

3) Kesalahan Operasi
Menurut Khasanah

(2015) menyatakan kesalahan terjadi ketika siswa dapat menentukan operasi yang harus dilakukan, tetapi tidak dapat melakukan prosedur operasi tersebut. Kesalahan perhitungan sering terjadi karena siswa tidak menguasai materi prasyarat. Siswa tidak mampu melakukan operasi-operasi bilangan bulat, bentuk akar dan bentuk operasi dasar seperti pembagian, perkalian, penjumlahan ataupun pengurangan. Banyak dari siswa yang masih mengalami kesulitan dalam menyelesaikan matematika dasar, sehingga berdampak siswa tidak dapat menghitung dengan tepat.

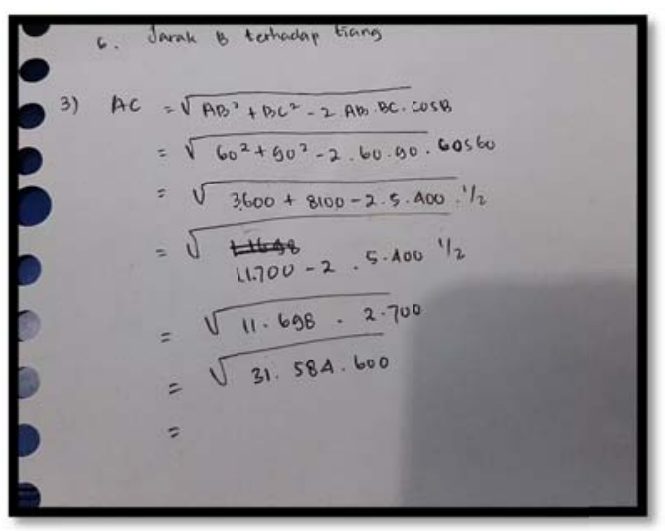

Gambar 3. Kesalahan Operasi

Berdasarkan jawaban tersebut, siswa melakukan kesalahan perhitungan dan tidak dapat menyelesaikan soal sampai selesai. Siswa tidak menguasai materi prasyarat yaitu operasi perkalian dan pengurangan pada bilangan bulat, hal tersebut dapat terjadi karena siswa tidak memilki konsep dasar matematika yang baik ditambah kurangnya latihan soal. Hal tersebut senada dengan Ningrum (2013) kesalahan pada aspek terapan yaitu kesalahan yang dilakukan siswa dalam rumus atau perhitungan soal cerita matematika.

\section{SIMPULAN DAN SARAN}

Pada soal cerita materi trigonometri siswa memenuhi indikator. Kesalahan konsep yang dilakukan siswa adalah siswa tidak mampu mengubah informasi yang diberikan ke dalam kalimat matematika, penyebab munculnya kesalahan ini siswa lupa menuliskannya. Kesalahan prinsip yang dilakukan siswa adalah siswa membaca soal kurang tepat sehingga terjadi kesalahan penafsiran, sulit memahami bahasa yang kurang familiar, mengakibatkan adanya kesalahan dalam menentukan rumus yang digunakan. Kesalahan operasi adalah adanya kesalahan perhitungan dalam betuk akar dan dan mengoperasikan bilangan penyebab 
$\pi$ (Phi)

munculnya kesalahan ini dikarenakan siswa kurang teliti melakukan perhitungan.

Berdasarkan hasil kesimpulan tersebut maka saran yang dapat diberikan untuk jenis kesalahan konsep yaitu: (1) Guru hendaknya menekankan pentingnya penyelesaian soal secara lengkap; (2) Membaca soal berulang-ulang; (3) Berusaha menterjemahkan maksud soal; (4) Guru hendaknya memperbanyak latihan soal sehingga siswa terbiasa dalam menghadapi soal serta untuk memperkuat ingatan siswa dan pemahaman siswa terhadap materi tersebut.

Alternatif pemecahan jenis kesalahan prinsip yaitu: (1) Guru hendaknya memberikan proses dari perolehan rumus yang ada sehingga siswa tidak hanya sekedar menghafal rumus tersebut; (2) guru hendaknya memberikan catatan di papan tulis dibuat sejelas mungkin sehingga tidak menimbulkan makna ganda.

Alternatif pemecahan jenis kesalahan teknis/ berhitung yaitu: (1) Dalam melakukan perhitungan hendaknya dilakukan dengan teliti. Oleh karena itu disarankan untuk memeriksa hasil perhitungan; (2) Membiasakan mengecek jawaban kembali dan menyesuaikan dengan konsep yang ada, untuk mengetahui masuk akal atau tidaknya suatu jawaban serta langkah penyelesaiannya.

\section{DAFTAR PUSTAKA}

Abdurrahman, Mulyono. (2010). Pendidikan bagi Anak Berkesulitan Belajar. Jakarta : Rineka Cipta.

Alfin Nurlaili Z, dkk. (2017). Analisis Kesalahan Siswa Dalam Menyelesaikan Materi Tigonometri. SIGMA : Vol. 3 No. 1 hlm 13.

Chusnul, Rr.C.,Mardiyana, \&Retno, D.S. (2017). Errors Analysis of Problem Solving Using The Newman Stage After Applying Cooperative Learning of TTW Type. International Conference
Jurnal Pendidikan Matematika

Volume 5 Nomor 1 Tahun 2021 and Workshop on Mathematical Analysis and its Applications, AIP Conf. Proc. 1913, 020028-1-020028-7.

Erliani, Eneng., Eli Rohmatullaeli, dan Nanang. (2011). Pembelajaran untuk Meningkatkan Kemampuan Membuat Model Matematika dari Soal Cerita. Jurnal PTK Khusus (1): 1-6.

Khasanah, Ummi. (2015). Kesulitan Menyelesaikan Soal Cerita Matematika Pada Siswa SMP. Surakarta.

Ningrum, Lilis S., dan Sri Sutarni. (2013). Analisis Kemampuan Siswa Menyelesaikan Soal Matematika dalam Bentuk Cerita Pokok Bahasan Barisan dan Deret pada Siswa Kelas XII SMA Al-Islam 3 Surakarta. Makalah disajikan di Seminar Nasional Pendidikan Matematika, Universitas Muhammadiyah Surakarta: 110-117.

Priyanto, A., Suharto, \& Trapsilasiwi, D. (2015). Analisis Kesalahan Siswa dalam Menyelesaikan Soal Cerita Pokok Bahasan Teorema Pytagoras Berdasarkan Kategori Kesalahan Newman di Kelas VIII A SMP Negeri 10 Jember. Artikel Ilmiah Mahasiswa (1), 1-5.

Sahriah. (2012). Analisis Kesalahan Siswa dalam Menyelesaikan Soal Matematika Materi Operasi Pecahan Bentuk Aljabar Kelas VIII SMP Negeri 2 Malang. Jurnal Pendidikan Matematika. 1 (1).

Sepeng, Percy, dan Sithembile Sigola. (2013). Making Sense of Errors Made by Learners in Mathematical Word Problem Solving. Mediterranean Journal of Social Sciences 4 (13): 325 333.

Sugiyono. (2016). Metode Penelitian Kuantitatif, Kualitati, dan $R \& D$. Bandung: Alfabeta.

Susanti. (2017). Analisis Kesalahan Siswa dalam Menyelesaikan Soal Cerita Program Linear berdasarkan Tahapan 


\section{$\pi$ (Phi)}

Newman. Jurnal Ilmiah Pendidikan
Jurnal Pendidikan Matematika Volume 5 Nomor 1 Tahun 2021

Matematika (6), 71-76.

Ika Diah Pratiwi, Aritsya, Yanti

Analisis Kesalahan Siswa Dalam Mengerjakan Soal Cerita Trigonometri 